\title{
The geography of Southern Persia as affecting its history
}

\section{Major P. Molesworth Sykes C.M.G.}

To cite this article: Major P. Molesworth Sykes C.M.G. (1902) The geography of Southern Persia as affecting its history, Scottish Geographical Magazine, 18:12, 617-626, DOI: 10.1080/00369220208733409

To link to this article: http://dx.doi.org/10.1080/00369220208733409

Published online: 27 Feb 2008.

Submit your article to this journal $\pi$

Џ Article views: 7

Q View related articles ๘

Citing articles: 1 View citing articles ๘ 


\section{THE SCOTTISH \\ GEOGR A P H I C L}

MAGAZINE.

\section{THE GEOGRAPHY OF SOUTHERN PERSIA AS AFFECTING ITS HISTORY.}

By Major P. MoLesworth Sykes, C.M.G., Gold Medallist of the Royal Geographical Society. ${ }^{1}$

Southern Persia and Baluchistán lie between the rich alluvial plains and ancient civilisations of the Euphrates, Tigris, and Karun on the west, and that of the Indus on the east. To the south, the land of Irán is washed by the Persian Gulf, which runs from NW. to SE., and is a most interesting body of water. Though proofs are still wanting, it is quite within the range of possibility that the art of navigation sprang into existence in this gulf, and that the pioneer ship of the mighty fleets of to-day painfully groped its way along these rockbound shores. Physically speaking, the coast is inhospitable, and the heat in summer is appalling. This latter fact must be remembered in connection with all schemes of development, the white man who resides on the shores of the Persian Gulf having to fight against a most trying climate. Additional disadvantages are the absence of good harbours and the fact that in the Persian Gulf there is always either too much or too little wind.

The coast strip runs back to range after range of rugged mountains increasing in altitude until the Irín plateau is reached. The fertile zone of upland country is not very wide, and it soon decreases in elevation, sloping down to the paralysing waste of the Lut.

The whole, indeed, can be best described as partly desert pure and simple, and partly desert tempered by oases. For instance, to the west, sonth, and east of Kerman there is desert, while at distances of a few miles, tiny hamlets, or in some cases villages, are kept alive by springs tapped in the hills, the water of which is laboriously conveyed for many

1 An Address delivered before Section $\mathbf{E}$ of the British Association at Belfast.

VoL. XVIII. 


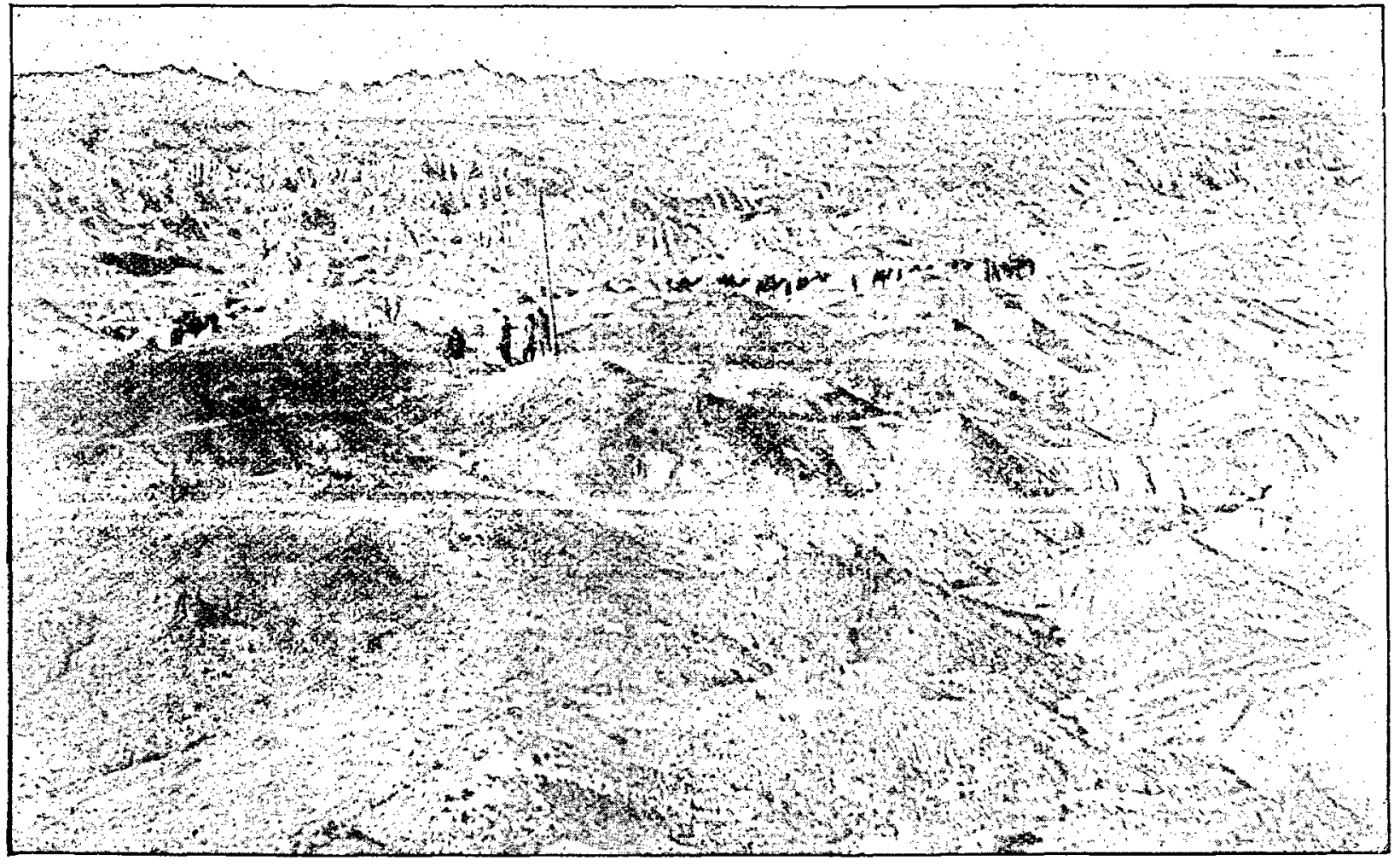

Makrín Scenery :-From Ten Thousand Miles in Persia. 
miles to the level plain by the underground channels termed kanats; in some cases the original well may be 400 feet deep, and as every few yards other wells must be dug, it is impossible not to admire the patient industry of the peasant who gains a living in spite of great difficulties, a heavy shower of rain or a sandstorm frequently choking up the kanát.

Throughout the twenty degrees of longitude which separate the Indus from the Shatt-el-Arab, no navigable river reaches the sea. Many of the rivers indeed, chief among which is the Helmand, discharge their waters into inlaud lagoons. This is an important point as affecting history, but still more important is the NW. to SE. trend of the mountain ranges, which, it is to be observed, run parallel to the coast. As they are pierced by no waterways, they form a most formidable barrier to communication from the sea, whereas from Tehrán, the capital, to Baluchistán, the traveller marches between parallel ranges of hills and along wide valleys, which fact in every way facilitates trade and traderoutes of every description.

We now turn for a few minutes to the province of Baluchistán in which I have made several journeys. Baluchistán is the generally accepted nomenclature of a huge, thinly peopled country, divided between the British and Persian Governments. 'This desert province roughly corresponds to the 17th satrapy of Darius as mentioned by Herodotus. The Great King invaded the Hapta Hindu or the Punjib, probably by the Baluchistán route, while a fleet under his Greek admiral Scylax descended the Indus, and, undismayed by the tides, explored the shores of Gedrosia and Arabia.

Baluchistán is termed Makrán throughout its coast regions, whereas the hinterland has no special name. Physically speaking, Makrán (see Fig.) consists of the district stretching inland as far as the watershed of the first important range of hills, and thus includes a strip of country averaging some sixty miles in width. For twenty miles from the coast there is a sandy plain traversed by several rivers, and often covered with tamarisk. Most of the rivers, except after rain, only run aboveground in parts, and then flow underground, which has the advantage of saving immense loss by evaporation.

Further inland the characteristics of the country are to a considerable extent similar to those of Southern Persia, except that the altitude of the mountain chains is not so great. As cultivation depends on irrigation, the absence of ranges sufficiently lofty to serve as storehouses for snow results in the encroachment of the Lut much further south. Indeed the eastern border of the Kerman province is separated from Baluchistán by a section of this desert some 200 miles in width, which is again an important factor in the history of Southern Persia.

I now turn to the Helmand delta (see Map), concerning the variable lower course of which I gained some interesting details when founding the consulate in Sistán nearly four years ago. Before describing this interesting example of what may be defined as the effect of history on geography, I propose to make a few remarks on this famous province. 


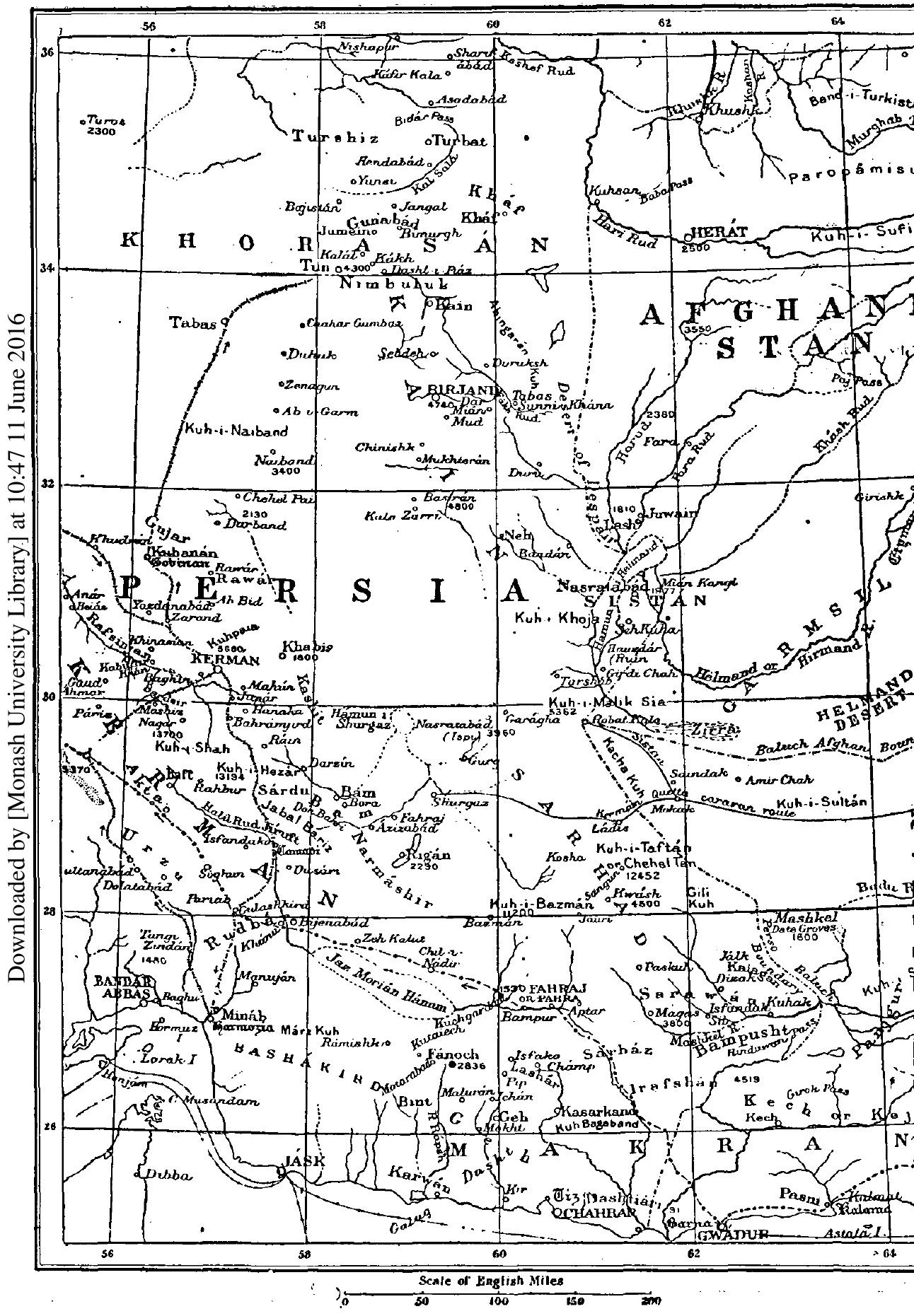


Sistan, that is to say, the lake and delta formed by the discharge of the Helmand and other less important rivers, was at some remote period one vast lake. Land was formed by the detritus brought down by the various rivers (of which the Helmand is by far the most important) along the northern portion of this lake, but this is now desert, while inhabited Sistan to the south was formed by the drying up of the lake itself owing to the decreased volume of the river, and perhaps also by the use of the water for purposes of cultivation.

Sistan of to-day has water on three sides for part of the year, the Helmand forming its eastern boundary, while to the north and west lies the hamun or lagoon (see Fig.). To the south-east of inhabited Sístán is situated the Gaud-i-Zirra or Hollow of Zirra, which is connected with the lagoon by the Shela, a watercourse 350 yards wide, with banks 50 feet high, where I crossed it. The great trough itself is at least 100 miles in length by 30 miles in width, and appears to have received either the whole of the present water-supply or the overflow of the old and greater flood; otherwise it is impossible to account for its vast area. The Shela runs in a briny stream when there is a large accession to the lake, and Captain Jennings describes the parallel waters of the Shela and Helmand flowing in opposite directions, with the lowest of sand-ridges intervening. Nowadays, as a rule, there is little more than a mar'sh in the lowest portion of the Gaud, not ten per cent. of its area being covered, even in springtime. If Ibn Haukal be correct, it would appear that in his day the Hirmand, as he always terms it, ran down to the Zirra Lake, which he describes as being 30 farsakh or about 100 miles in length when full. This would seem to settle the question.

I would now return to the Helmand, the classic Etymander. To summarise its courses, in the fourteenth century there was a solid dam known originally as the Band-i-Rustam and later as Band-i-Akwa (evidently a corruption of Afghán or Agwán). This was situated at a point on the Helmand some 40 miles east of the ruins of Hauzdar and at an equal distance from the limits of Sistán as it is to-day. A deep canal running west irrigated the fertile plain of Hauzdár, the main stream flowing north under the name of Rud-i-Nasru. On its banks were the famous cities of Shahristán and Záhidan.

Towards the close of the fourteenth century Sistan was invaded by Timur or Tamerlane, who destroyed the dam, and thus reduced the Hauzdár plain to a waterless desert. This action affected the Helmand, which, while still keeping to the Rud-i-Nasru, created a second branch encircling Sehkuha, which had not hitherto been inhabited.

There was apparently no other change until early in the nineteenth century, when the whole volume of water united to carve out a channel further east, to the west of the village and mound of Nád-i-Ali. As cultivated Sístán was thereby left high and dry, the Rud-i-Sístan was cut a little to the north of Sehkuha-a task of great magnitude. Such was the state of affairs when some thirty years ago Sir Frederic Goldsmid made his award, by which the river formed the boundary between Persia and Afghanistan, but, in 1896, the Helmand began to forsake the Níd-i-Ali channel and struck out a new course between it and the Rud-i- 


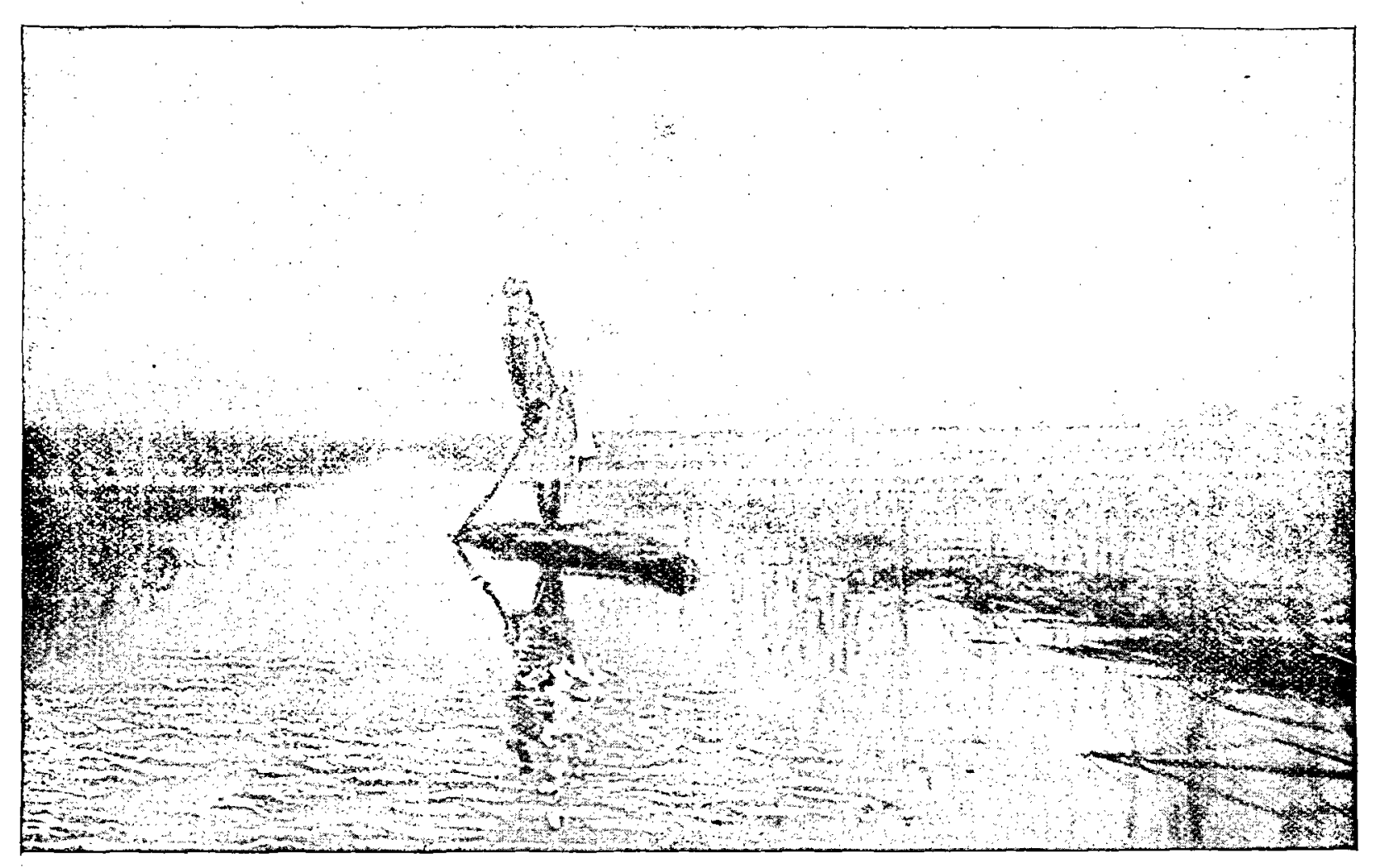

The Helmand Lagoon :-From Ten Thousand Miles in Persia. 
Nasru. This is now known as the Rud-i-Perián, and was a fine river when I crossed it on a reed raft in 1899. It is, however, anticipated by the greybeards of Sístán that the wayward Helmand will finally return to the ancient Rud-i-Nasru.

To conclude this brief survey, I would now refer to the Lut (see Fig.), perhaps the most salient characteristic of Persian physical geography. It is considered that in early times it was an inland sea, which theory is supported by the presence of the active volcano of Sarhad, the extinct volcano of Bazman, and many legends. But this is rather a geological question which I am not competent to discuss. Geographers have, without sufficient reason, I would urge, divided the great desert of Persia into two separate regions; that to the north being termed the Dasht-i-Kavir, the southern part being known as the Dasht-i-Lut.

The word Kavir is undoubtedly the Arabic word $K a f r$, which signifies a saline swamp, and is used in this connection in Southern Persia if not in the north. As regards the term Lut, the guides point out fantastic bluffs, resembling forts, mosques, or cathedrals, and explain that they are ruins of cities which the Almighty destroyed, as was the case with the cities of the plain from which Lot escaped with so much difficulty. This great waste of Persia thus has become associated and most appropriately, as I would maintain, with the name of Lot, Abraham's nephew.

After having made constant inquiries, I have come to the conclusion that the whole desert bears the one name of Lut, and that its saline portions are known as Kavir or Kafr.

This great desert stretches from a few miles out of Tehrán practically to the British frontier, a distance exceeding 700 miles, while from Tun to Pahra is about. 500 miles. The easterly edge appears to be the highest, the village of Basiran, which $I$ visited in 1899 , lying at an altitude of 4800 feet. Tun is 4300 feet, and elsewhere the average elevation may be perbaps 2000 feet. Near Khabis the lowest levels appear to be about 1000 feet.

The worst portion of the Lut is that lying between Eastern Persia and Khabis, which was crossed by $M$. Khanikoff in the middle of the nineteenth century, and was twice traversed by Captain Galindo in the eighties. The former traveller writes: "Our delight at finding ourselves safe and sound can easily be imagined after crossing a desert unequalled in aridity on the whole of the Asiatic continent, for the Gobi and Kizil-Kum are fertile prairies compared to the Lut. I have seen the dreary aspect of the Isthmus of Suez. Many parts of that arid region seem struck with the same sterility as the Lut, but it never retains that character over such a vast surface." As M. Khanikoff possessed such a wide field for comparison, I think that his views may be accepted as final.

As I have crossed the Iut in many directions, my acquaintance with it may be considered to be somewhat extensive. Before coming to Persia the only desert I had seen was that of Suez, which is apparently an unlimited expanse of yellow sand. Not that vast tracts covered with yellow sand do not exist in the Lut, the interesting Seljuk column being situated in one of these level expanses. But in other parts are high mountains 


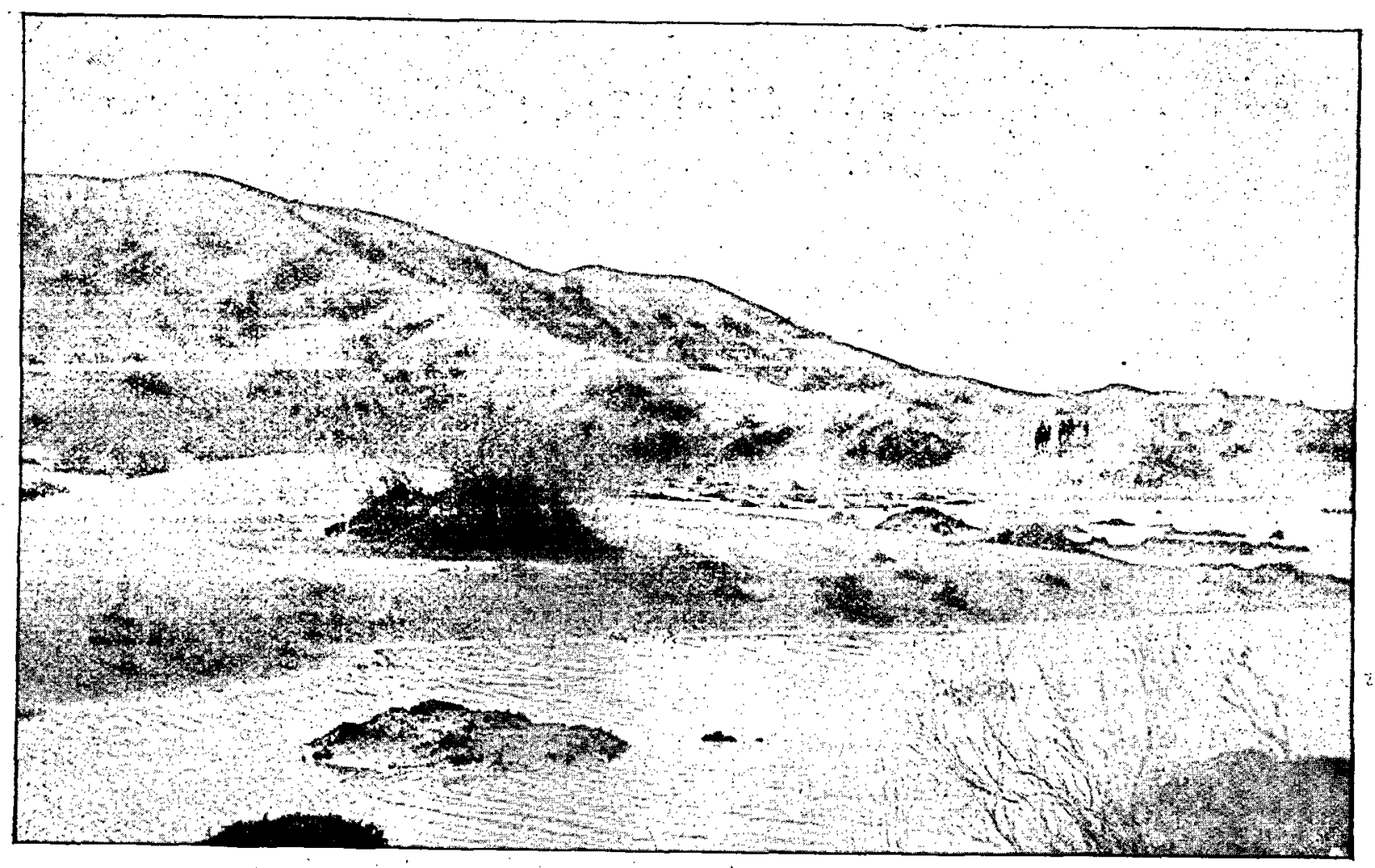

The Lut:-From Ten Thousand Miles in Persia. 
-I discovered one range with snow on its peaks in March-while again there are limitless wastes of gravel. In all cases, however, there is little or no drinkable water, so that these funereal wilds form a terribly formidable hindrance to communications, and thereby influence the countries which they embrace in a paralysing grasp.

To summarise, Southern Persia and Baluchistán have ever been comparatively barren countries, most difficult of access from the coast, and in consequence they have escaped invasion by sea, while Northern and Southern Persia have always suffered from the terrible Lut. Owing to the hardening influence of a livelihood wrested from a sterile soil, and perhaps still more to the superb climate, a warlike race was produced which frequently held in subjection the inhabitants of the rich, low-lying plains to the west, while, more than once, the martial hosts of Irán have swept all before them in the plains of India.

It is, however, with modern developments that I propose to conclude this paper, and I can give no better instance of my theme than that afforded by the Indo-European telegraph line.

Persia emphatically lies on the "High way of the Nations," and when a land telegraph line to India was decided upon, there was no question as to the land of Irin lying across its route. Owing to the fact that at the end of the eighteenth century Shiráz became the capital of Kerim. Khán, the soldier of fortune who carved out a kingdom for himself, the Bushire-Shiráz track-infamous though it is - superseded the routes from Bandar Abbas, which, geographically speaking, are by far the best, and were used by all travellers from the time when European ships first appeared in Eastern waters.

However, the Bushire-Shiráz-Isfahán-Tehrán route still remains the chief trade-route of Persia, and thus some thirty or more years ago the first telegraph line entered the kingdom of the Shah near Tabriz, and passing through Tehran, followed this route to Bushire. From Bushire there are two cables which run the entire length of the Persian Gulf to Jásk, and from that village--the point where Englishmen first landed to open up trade with Persia in 1618-there is a land line which traverses the entire length of Makrán and joins the Indian system at Karachi.

A glance at the map will show that this line runs along two sides of a triangle; consequently it is not surprising that when in 1896 the undefined section of the boundary between Persian and British Baluchistán was finally delimitated by our president, Sir Thomas Holdich, under whom I had the honour to serve, ideas of a more direct line of communication came to be considered both desirable and feasible.

Already, in 1894, I had drawn attention to this subject, and in 1898 Mr. King Wood, of the Telegraph Department, accompanied me from Isfahán eastwards to reconnoitre.the country for this purpose.

The extraordinarily regular $\mathrm{NW}$. to $\mathrm{SE}$. trend of the orographic system of Persia left no doubt as to the course to be followed for some 500 miles, so that from Káshán, where the present system is quitted, the new telegraph line will run down a wide valley to my headquarters at Kermán. From this city, the capital of South-Eastern Persia, the same 
wide valley is followed as far as Bam and Narmáshir, which lie on the eastern edge of the Lut.

In $1894 \mathrm{I}$ had discovered the village of Bazmán lying at the southern end of a volcanic range with a peak running up to over 11,000 feet, and as this practically bisects the desert, the telegraph line will be constructed to Bazmán. From this village its eastward course cannot be settled until it be decided whether Quetta or Karachi is to be its objective. But I think that the description I have given proves very fully how the direction taken a Central Persia has been entirely decided by the geography of the country.

\section{TEN THOUSAND MILES IN PERSIA. ${ }^{1}$}

IT may not be inappropriate that the preceding article should be followed by some account of the work on Persia recently published by Major Sykes. Between 1893 and 1901 Major Sykes made many journeys in Persia, travelling throughout it northwards and southwards, and, both inland and along its southern coast, eastwards and westwards. His first journey was made in his private capacity as one who had felt the fascination of "romantic Irán." In the others, some of which included prolonged residence in certain districts, he was employed as an agent of the Government of India or the British Foreign Office. His official relations had reference chiefly to Southern and Eastern Persia. His wanderings in connection with them lay mostly, though by no means exclusively, in and around the extensive region reaching from the Kárun on the west to Beluchistán on the east, and from the Persian Gulf and Makrán coast on the south northward to the Lut and Sistán. They enabled him to obtain an intimate acquaintance with the geographical features and physical resources and condition of this part of Persia. He evidently acquired a complete command of the speech of the country, the most delectable perhaps of living Eastern tongues, and a large knowledge of its literature. With this was apparently combined a genuine liking for Orientals of the Persian type. He thus got into close touch with the people, gaining thereby a varied and trustworthy insight into Persian affairs. The result has been a really noteworthy book, charming in its narrative and descriptions, and replete with information of divers sorts concerning men and things-ancient, mediæval, and modern : the fruit not only of personal observation and experience, but of much literary and historical research and study.

We are, according to an oft-repeated commonplace, approaching the time when on this earth of ours no fresh domain will be found for the geographical explorer. But Major Sykes's work illustrates the contention that even in countries longest known to history there remains to the

I Ten Thousand Afiles in Persia, or Eight Years in Iran. By Major Perey Molesworth Sykes (Queen's Bays), H.M. Consul, Kermán and Persian Beluchistán. London: John Iurray, 1902. Pp. xv+481. Price 25s, net. 